\title{
Determinants And Impact Of CSR Assurance: Empirical Study In Public Companies In 2016
}

\author{
Calvina and Melinda Haryanto \\ Faculty of Business School \\ University of PelitaHarapan, Tangerang \\ melinda.haryanto@uph.edu
}

\begin{abstract}
This study aims to examine the influence of industry type, leverage, operational coverage on CSR Assurance and CSR Assurance impact on firm value. The population of this research is a public company contained in the list of Forbes Global 2000 in 2016. Samples taken in this study as many as 200 samples by using purposive sampling method. The analysis model used in this research is logistic regression model and multiple linear regression model. The results showed that industry type and operational coverage proved to have a significant positive effect on CSR Assurance. However, leverage is not proven to have a significant negative effect on CSR Assurance, but research results show that leverage has a significant positive effect on CSR Assurance. In addition, CSR Assurance proved to have a significant positive effect on company value.
\end{abstract}

Keywords: CSR Assurance, industry type, leverage, operational coverage, company value.

\section{INTRODUCTION}

Sustainability reporting is a process where companies measure, disclose, and strive to become an accountable company for all stakeholders with the aim that the company achieves sustainable development. The results of this reporting activity are sustainability reports. In this report, the company reveals the influence of its performance on economic, social and environmental aspects.

Over the past few years, there has been a significant increase in the number of sustainability reports issued by companies in the world. This is evidenced by a survey conducted by the Governance and Accountability Institute which stated that in 2013, around $72 \%$ of companies registered with The Standard \& Poor's 500 had published sustainability reports in various forms. These results show a significant increase compared to the results of the survey in 2011 which only reached below $20 \%$.

According to the AICPA (American Institute of Certified Public Accountants), companies are beginning to realize that disclosure of sustainability information is not enough, but decision-makers need to believe that the information can be trusted. One solution that can increase the reliability of sustainability information is to obtain assurance service from third parties

According to SGS (SociétéGénérale de Surveillance), assurance from an independent party is considered to provide added value to the information conveyed in the sustainability report itself. One of SGS's clients, GlaxoSmithKline, revealed that thirdparty assurance not only increases the credibility of information, but also provides many 
other benefits such as improving data quality, increasing confidence levels in measuring the progress and successes the company has achieved, and increasing the efficiency of the sustainability reporting process

Along with the increasing number of sustainability reports issued by the company, stakeholders also pay more attention to third party of CSR (Corporate Social Responsibility) assurance. This statement is supported by the results of a survey by KPMG (Klynveld Peat Marwick Goerdeler) which revealed that 59\% (majority) of G250 (Global Fortune 250) companies that issued sustainability reports had invested in external assurance in 2013, while only 29\% in 2002. According to the GRI (Global Reporting Initiative), this happens because sustainability reports are considered to be a tool that is able to assess the current condition of the company and the prospects of the company.

The increasing world attention to sustainability has made many parties interested in the reasons behind the disclosure of sustainability reports and the acquisition of third party CSR assurance by the company. Over the next 10 years, a study by Verdantix of companies in America found several factors that influence sustainability reporting and third party CSR assurance. Some direct influential factors include government regulations, stock exchange activities, and requests for business-to-business information. Some indirect factors include investor attitudes, consumer attitudes, environmental degradation and progress in business. In addition, the type of industry influences the decision to obtain a third party assurance CSR (Cho et al., 2014). Based on research conducted by (Brancoet al., 2014), leverage has a negative influence on CSR Assurance. Whereas companies with wider operational scope or internationally have a tendency to obtain CSR Assurance from external parties.

Based on research conducted by GRI that companies invest in CSR assurance because external assurance itself brings several benefits. One of the benefits that is the main target of the company is the reduced risk and increasing corporate value. According to (Indyanti, 2017) where it is stated that companies that present assurance statements tend to have higher corporate values. But this is different from the research of (Cho et al., 2014) which states that companies that issue CSR Assurance have no effect on company value

Several previous studies are studies conducted by (Cho et al., 2014;Branco, 2014; Indyanti, 2017; and Rakhman, 2017) who examine the factors that encourage companies to obtain external assurance for sustainability reports. Previous research by (Cho et al., 2014) was limited to companies in America for 2010. Research by (Branco, 2014) was limited to companies in Portugal. Research by (Indyanti, 2017) is only limited to nonfinancial companies in Indonesia during 2012-2014. Meanwhile, research by (Rakhman, 2017) is only limited to companies listed on the Indonesia Stock Exchange for the period 2012-2014. Previous results indicate that the gap between (Cho et al., 2014; Branco, 2014) study relates to factors that influence companies in issuing CSR Assurance where according to (Cho et al., 2014;Rakhman, 2017) leverage has no significant effect whereas according to (Branco, 2014) leverage has a significant negative effect. Industry type factors have a significant positive effect (Cho et al., 2014;Branco, 2014; and Indyanti, 2017) whereas according to (Rakhman, 2017) there is a significant negative effect on CSR Assurance.

This research uses public companies listed in the Forbes Global 2000 list in 2016 as samples, where research on this sample has never been done before. The initial 
phenomenon, $10 \%$ of the largest companies of companies listed in Forbes Global 2000 showed $61.5 \%$ of companies that issued CSR Assurance while the rest did not issue. When viewed from positive things that exist from the issuance of CSR Assurance, this results in a gap between the theory and the reality that occurs in the field. If CSR Assurance is believed to be able to increase the value of the company but there are still few companies that issue CSR Assurance. Thus this research is conducted to analyze what factors influence the company in making decisions to obtain assurance of CSR from third party, as well as the impact of CSR Assurance on company value. Based on the statement, this study is entitled "Determinants and Impacts of CSR Assurance: Empirical Studies in Public Companies in 2016".

\section{THEORETICAL REVIEW}

Signaling Theory. According to (Ross, 1977), companies will be compelled to convey this information to prospective investors if the company's executive has better information about the company. Signaling theory explains how companies give signals to external parties. This signal contains information about what has been done by the company and targets that will be realized in the future. The signal delivered can be in the form of promotion or other information which states that the company is better than other companies (Falichin et al., 2011).

According to (Lako, 2010), signaling theory states that companies that care and disclose CSR information give a positive signal to the market. By disclosing CSR, companies can signal to the community by showing their past performance and explaining the company's targets in the future. In the end, a good signal can attract new prospective investors. This can be one of the factors driving companies to disclose CSR.

In addition, CSR reports can be more trusted if they get assurance or reviews from third parties. External assurance provides several competitive advantages for the company, including improving the company's reputation, improving the quality of risk management and others. Therefore, the existence of CSR Assurance from external parties is believed to be able to provide a signal and provide a better CSR message for investors and other stakeholders (Cho et al., 2014).

CSRD (Corporate Social ResponsibilityDisclosure). Disclosure of Corporate Social Responsibility is the process of communicating the social and environmental impacts of an organization's economic activities towards specific groups of interests and to the community as a whole. This broadens the responsibilities of the organization (especially the company), in addition to its traditional role in providing financial reports to capital owners, especially shareholders. The expansion was made with the assumption that the company has broader responsibilities than just seeking profits for shareholders (Gray, 2001).

Disclosure of corporate social responsibility is the process of communicating the social and environmental impacts of an organization's economic activities towards specific groups of interests and to the community as a whole. This broadens the responsibilities of the organization (especially the company), in addition to its traditional role in providing financial reports to capital owners, especially shareholders. The expansion was made with 
the assumption that the company has broader responsibilities than just seeking profits for shareholders (Gray, 2001).

According to (Haryanto and Dewiyanti, 2017), the three benefits of disclosure of social responsibility carried out by companies are as follows: (1) to improve the company's image (2) improvement of the company's vision and mission (3) cost savings. One concept of CSR disclosure that is developing in Indonesia is the Global Reporting Initiative (GRI). Disclosure of social responsibility can be measured by the proxy of the Corporate Social Responsibility Disclosure Index (CSRDI) based on the Global Reporting Initiatives (GRI). This GRI indicator consists of three disclosure focuses, namely economic, environmental and social as a basis for sustainability.

One concept of CSR disclosure that is developing in Indonesia is the Global Reporting Initiative (GRI). Disclosure of social responsibility can be measured by the proxy of the Corporate Social Responsibility Disclosure Index (CSRDI) based on the Global Reporting Initiatives (GRI). This GRI indicator consists of three disclosure focuses, namely economic, environmental and social as a basis for sustainability

CSR Assurance. One way to increase a company's credibility is through broader voluntary disclosures to help investors understand business management strategies. One form of voluntary disclosure is disclosure of sustainability known as CSR disclosure. Signaling theory is the theory underlying this voluntary disclosure.

Along with the increase in the number of companies that publish sustainability reports, stakeholders began to realize that there are needs to be assurance or review from an independent party like other financial reports. Assurance is the result of an independent verification process. Assurance is used to explain evaluations and assessments by independent accounting institutions which are usually carried out based on certain standards and frameworks.

Assurance is believed to be able to make stakeholders more confident about the quality of the information reported in the sustainability report. Assurance statements are in line with the principles of good CSR reporting, including transparency and accountability (Cho et al., 2014). The importance of assurance of sustainability reports has been recognized by the GRI (Global Reporting Initiative) since it was published in 2002. In the G4 Guidelines, GRI recommends that companies obtain assurance of sustainability reports, although not mandatory and do not need to be reported in accordance with the G4 Guidelines's format.

Industry Type. Industrial type is one form of characteristic difference that can be used to test social disclosure. Industrial types can be divided into two types, namely high profile and low profile. According to (Andriyanto and Metalia, 2011), companies included in the type of high profile industry are companies that have high sensitivity to the environment, a high level of political risk, or a strong level of competition. The high profile industry is believed to do more social responsibility disclosure than the low profile industry. Companies with a high level of sensitivity, which have higher environmental and social impacts tend to issue CSR Assurance to gain legitimacy from the public (Cho et al., 2014; Indyanti, 2017) 
Leverage. Basically, the company's operational activities rely on equity and debt. Leverage ratio is one of the measuring instruments for assessing the proportion of debt and equity in the company's capital. In addition, the leverage ratio is also used to measure the company's ability to fulfill its financial obligations in the future.

One of the most commonly used for leverage ratios is the Debt-to-equity ratio. The $\mathrm{D} / \mathrm{E}$ ratio indicates the amount of corporate debt compared to the total equity of the company. The results of the calculation can be either percentage or number. Every industry has its own benchmark for the Debt-to-equity ratio.

Operational Coverage. The operational scope of the company is the area or scope of the area where the company operates. The company can have operational coverage in the country (national) or overseas (multinational). Stakeholders have different desires and strengths and pressures, for example in developing countries, consumers and interest groups have relatively small strengths and pressures to encourage companies to disclose environmental information (Suhardjanto and Miranti, 2009). Therefore, the demand to report environmental information is higher for companies operating in various countries than only operating on the domestic market. (Haniffaand Cooke, 2005) states that the pressure to legitimize companies in developed countries is higher than in developing countries.

Stakeholders have different desires, strengths and pressures, for example in developing countries, consumers and interest groups have relatively small strengths and pressures to encourage companies to disclose environmental information (Suhardjanto andMiranti, 2009). Therefore, the demand to report environmental information is higher for companies that operating in various countries than only operating on the domestic market. (Haniffaand Cooke, 2005) states that the pressure to legitimize companies in developed countries is higher than in developing countries.

The value of the company. Company value is an economic measure as an illustration of public trust in the company after going through the operational activities for a certain period. The value of the company also reflects the market value of a company. Company value can be reflected in the value of its shares. This is because the company increases the value of the company through increasing the prosperity of the shareholders (owners). A high corporate value will be followed by high shareholder prosperity (Husnan, 2008). This research uses market value as a tool to measure company value.

Research Background. Several previous studies related to CSR Assurance produced various findings and results. The following are previous studies which were the references in this study. 
Table 1. Research Background

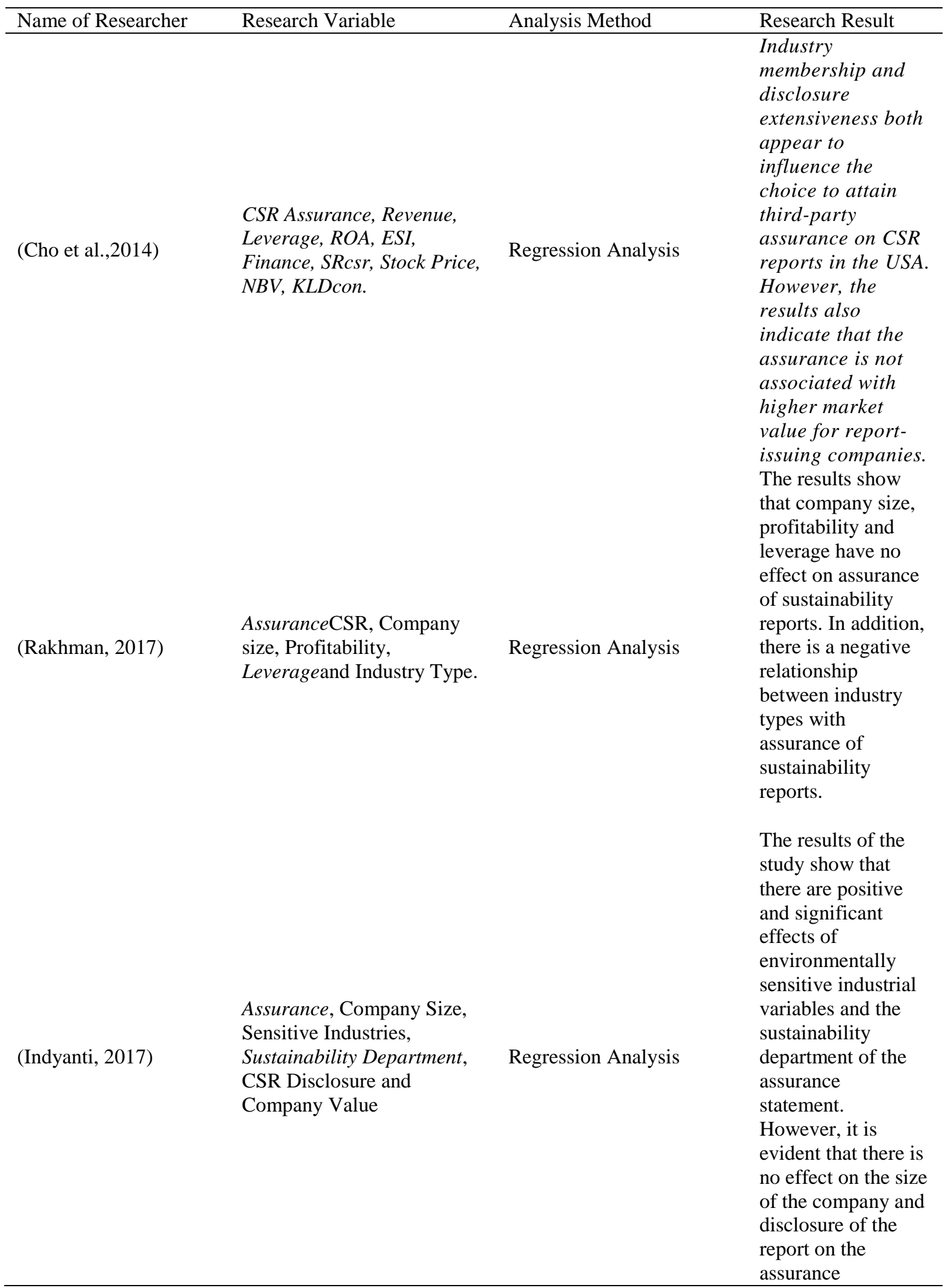


statement. In addition, there is evidence that companies that present assurance statements tend to have higher corporate values.

ROE, ROA, EPS, PER and DER have

(Wibowo, 2016)

$$
\begin{aligned}
& \text { Stock price, } R O E, \text { ROA, } \\
& \text { EPS, PER dan DER }
\end{aligned}
$$

Percentage of Management Ownership, Leverage,

(Ikhwandarti et al., 2010)

(Branco et al., 2014)

\section{Company Size, Industry}

Types, Profitability, Social Information Disclosure, Firm Value.

size, leverage, profitability, listing status and industrial affiliation, type of ownership is not.
Explanatory research method

Path analysis

Logistic Method
The industry types have significant effect toward the social information disclosure, the percentage of management ownership have significant effect toward the firm value and the industry types have significant effects toward the firm value.

Regression

size, leverage, profitability, listing status and industrial affiliation are determinants of SRA, whereas type of ownership is not. A downward trend in sustainability reporting and its assurance was also detected.

Source: Previous Research 
Framework
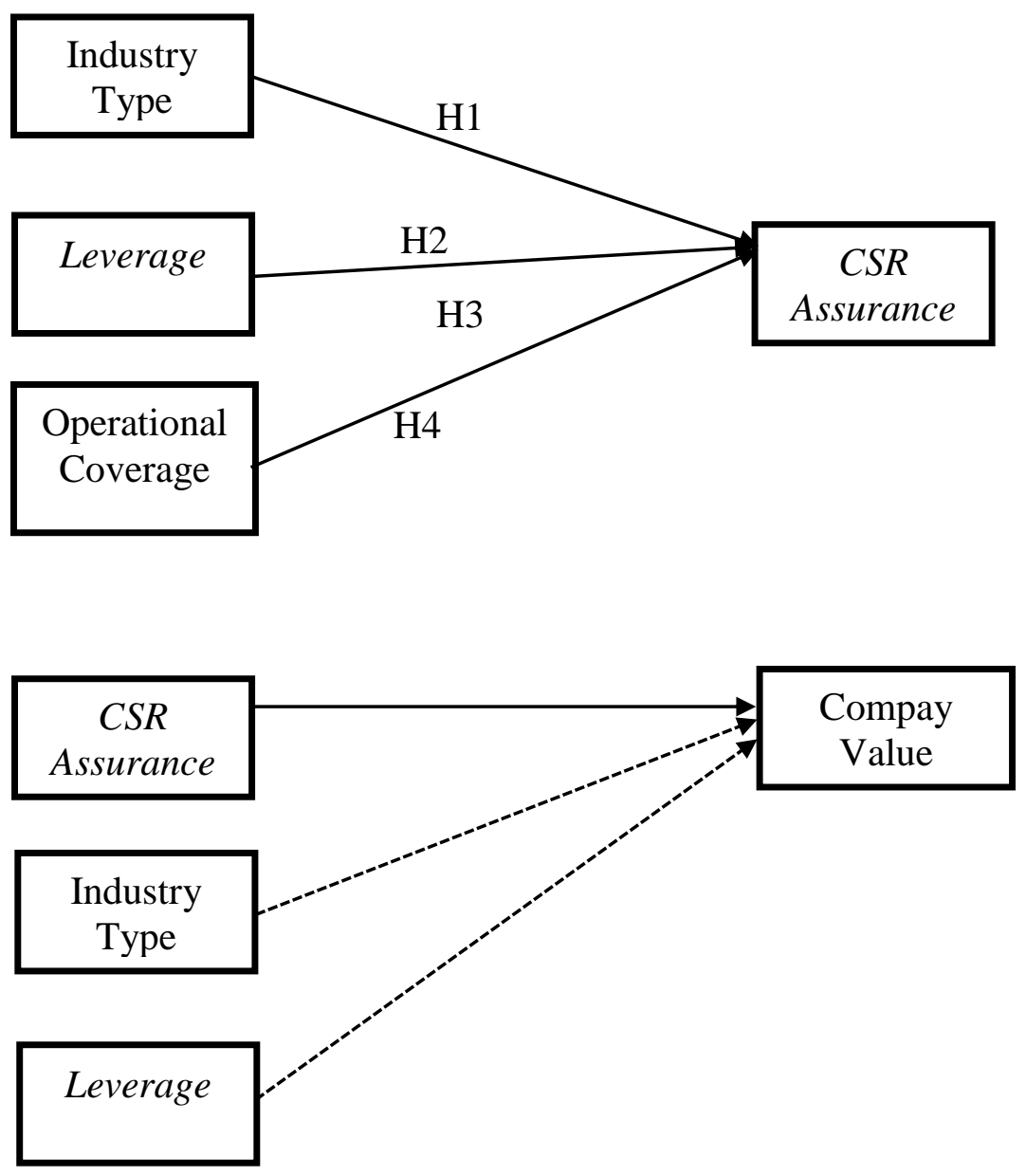

Figure 1. Framework

An explanation of the framework is outlined in the hypothesis below. Development of Hypotheses

Industrial Type Has Positive Significant Impact on CSR Assurance. According to (Utomo, 2000), accounting researchers are interested in testing social disclosures in various companies that have different characteristics. One aspect that is a difference in company characteristics is the type of industry, namely the High Profile and Low Profile industry types. The research conducted by (Cho et al., 2014) states that company characteristics, especially industry types, influence CSR Assurance. The results of these studies are also supported by research conducted by (Indyanti, 2017) which states that industry types have a significant positive effect on assurance statements. However, different results were found in the study by (Rakhman, 2017) where he stated that the existence of a negative relationship between industry types and assurance of sustainability reports. Because of the differences in the results of previous studies, the hypothesis is proposed as follows

H1: Industrial type has a significant positive effect on CSR Assurance. 
Leverage Has Negative Significant onCSR Assurance. Based on capital theory, companies with a high degree of leverage tend to be reluctant to invest both in sustainability reporting and assurance from third parties that cost a lot. Companies with high levels of leverage have a closer relationship with their creditors. Therefore, CSR reporting is considered unnecessary for highly leveraged companies. Previous research by (Moussuet al., 2014) states that there is a negative relationship between corporate debt and CSR. Meanwhile, research conducted by (Cho et al., 2014) states that there is no significant relationship between leverage and CSR Assurance. (Rakhman, 2017) also show that leverage is not a determinant in CSR Assurance. Based on the description above, the hypothesis is proposed as follows:

H2: Leveragehas a significant negative onCSR Assurance.

Operational Coverage Has a Significant Positive Impact on CSR Assurance. Based on signal theory, companies that have a broad scope to go abroad tend to convey broader and more quality corporate CSR information in order to accommodate the wishes of shareholders abroad in obtaining information that the company has carried out its social responsibility well. Therefore, sustainability reports should be transparent and reliable, where this can be achieved by obtaining assurance from third parties. However, the results of (Bawono, 2015)'s research show results that are not in harmony with the theory that operational coverage has no significant effect on corporate CSR disclosure. Based on the description above, the hypothesis is proposed as follows:

H3: Operational coverage has a significant positive impact on CSR Assurance

CSR Assurance Has a Significant Positive Impact on Corporate Values. CSR Assurance is believed to increase the credibility of the sustainability report. According to (Clarkson et al. (2008) in Cho et al. (2014)), companies disclose activities that are difficult for investors and other stakeholders to observe. Therefore, in accordance with the signaling theory, sustainability reporting with assurance from third parties that provides positive signals to stakeholders is believed to increase the value of the company. The results of (Indyanti, 2017) study support signal theory where evidence is found that companies that present assurance statements tend to have higher corporate values. However, research by (Cho et al., 2014) found that CSR Assurance had no effect on company value. Based on the description above, the hypothesis is proposed as follows:

H4: CSR Assurance has a significant positive effect on firm value.

\section{METHODOLOGY}

Population, Sample and Source of Data. The population in this study were all companies listed in Forbes Global 2000 for 2016 and the company issued a sustainability report. The selection of companies listed in Forbes Global 2000 is due to the SEC (Securities Exchange Act of 1934) that listed companies are required to publish annual reports to all stakeholders, including external parties. In addition, data was selected from 2016 to obtain research results that better illustrate the latest or updated conditions of the factors that influence the company's CSR Assurance and their effect on company value.

The sampling method used in this study is purposive sampling method, where sampling method is only on predetermined samples based on the aims and objectives of 
the study. Criteria in sample selection are 1) companies in Forbes Global 2000. 2) Companies that publish and publish sustainability reports for 2016.

Samples will be taken from the total population of companies listed in Forbes Global 2000 in 2016 of 2000 companies. This study took a sample in the 2016 analysis period. The type of data used in this study is secondary data, where data is obtained indirectly from sources and through intermediary media.

Empirical Model of Research. This research was conducted by collecting data and then the data was processed and analyzed using descriptive statistical tests, classic assumption tests, regression model tests, model feasibility tests and hypothesis testing. Therefore, this test uses the regression equation as follows:

1. First Equation (Logistic Regression)

$\mathrm{CSRA}_{\mathrm{i}}=\alpha+\beta_{1} \mathrm{ESI}_{\mathrm{i}}+\beta_{2} \mathrm{LEV}_{1}+\beta_{3} \mathrm{OP}_{1}+\mathrm{e}$

Description:

CSRA $_{1}$ : CSR Assurance from third party

ESI $_{1}$ :industry type (environmentally sensitive industry)

$\mathbf{L E V}_{\mathbf{1}}$ : leverage

$\mathbf{O P}_{\mathbf{i}}$ :operational coverage

2. Second Equation (Linier Regression)

MARKETVALUE $_{\mathrm{i}}=\alpha+\beta_{1}$ CSRA $_{\mathrm{i}}+\beta_{2}$ ESI $_{1}+\beta_{3}$ LEV $_{1}+\mathrm{e}$

Description:

MARKETVALUE $_{1} \quad$ : $\quad$ Market Value from company

CSRA $_{1} \quad: \quad$ CSR Assurance from third party

ESI $_{1} \quad$ : $\quad$ industry type

$\mathbf{L E V}_{\mathbf{1}} \quad$ : leverage

Definition of Operational Variables

Dependent Variable. Dependent variable is used in this study is CSR Assurance at first model and company value at second model. Variable CSR Assurance variable is measured using dummy variable with criteria : If there is CSR Assurance in sustainability reporting $=1$, it there isn't CSR Assurance in sustainability reporting $=0$

Value of the company variable is measured using the company's market value on December 31, 2016

Independent Variable.Independent variables is used in this study are industry type, leverage, operational coverage (first model) and CSR Assurance (second model).

Industrial type variables are measured using dummy variables, namely $1=$ companies included in the high profile industry, $0=$ companies included in the low profile industry. The leverage variable is measured using Debt-to-Equity Ratio: Total Debt / Total Equity. Operational coverage variables are measured using dummy variables, namely 1: Multinational, 0: National

Control Variable. Control variables is used in second model are industry type and leverage 
Statistical test applied in the research. In this study, logistic regression test is used to test first model and multiple regression tests is used to test second model. In multiple regression there is a classic assumption test (normality test, multicollinearity test and heteroscedasticity test) and hypothesis testing using $t$ test and $F$ test. This study uses an analysis tool or software in the form of E-Views.

\section{THE RESULTS OF STATISTICAL TESTS}

Research Sample. The object of research is used in this study is the company contained in Forbes Global 2000 for 2016 and meets the specified criteria. Based on data obtained from the Forbes.com website, there are 2000 companies included in the Forbes World's Biggest Public Companies list for 2016. Of these, only 200 of the largest companies are sampled or $10 \%$ of the total number of companies listed. This is done because the 200 largest companies in the world can represent other small companies in the world.

\section{Testing the First Equation}

Feasibility Test Model. The probability of LR statistics is 0.000004 where the value is smaller than the test significance level of 0.05 . Therefore, at a $95 \%$ confidence level it can be concluded that the research model is feasible in this study (see table 2)

In table 2 also shows that the McFadden R-Squared value is 0.103732 . This value shows that the type of industry, leverage and operational coverage has a proportion of influence of $10.37 \%$ on CSR Assurance, while the remaining $89.63 \%$ is influenced by other variables not contained in the logistic regression model.

Result of Logistic Regression Test. Based on logistic regression test, we can compile the mathematical equation of the logistic regression model as follows:

$\operatorname{CSRA}_{i}=-0,979+0,75 E S I_{i}+0,047 L E V_{i}+0,770 P_{i}$

Logistic regression test can be seen at table 2

Table 2. Multiple Linier Regression Result

Dependent Variable: CSRA

Method: ML - Binary Probit (Quadratic hill climbing)

Date: 08/12/17 Time: $12: 13$

Sample: 1200

Included observations: 200

Convergence achieved after 4 iterations

Covariance matrix computed using second derivatives

\begin{tabular}{|c|c|c|c|c|}
\hline Variable & Coefficient & Std. Error & z-Statistic & Prob. \\
\hline $\mathrm{c}$ & -0.979903 & 0.281751 & -3.477907 & 0.0005 \\
\hline ESI & 0.750298 & 0.216875 & 3.459581 & 0.0005 \\
\hline LEV & 0.047941 & 0.018877 & 2.539677 & 0.0111 \\
\hline OP & 0.771221 & 0.251641 & 3.064764 & 0.0022 \\
\hline McFadden R-squared & 0.103732 & & 0.615000 \\
\hline S.D. dependent var & 0.487816 & \multicolumn{2}{|c|}{ S.E. of regression } & 0.456158 \\
\hline Akaike info criterion & 1.234651 & \multicolumn{2}{|c|}{ Sum squared resid } & 40.78379 \\
\hline Schwarz criterion & 1.300618 & \multicolumn{2}{|c|}{ Log likelihood } & -119.4651 \\
\hline Hannan-Quinn criter. & 1.261347 & \multicolumn{2}{|c|}{ Restr. log likelihood } & -133.2918 \\
\hline LR statistic & 27.65328 & \multicolumn{2}{|c|}{ Avg. log likelihood } & -0.597326 \\
\hline Prob(LR statistic) & 0.000004 & & & \\
\hline Obs with Dep $=0$ & 77 & \multicolumn{2}{|l|}{ Total obs } & \multirow[t]{2}{*}{200} \\
\hline Obs with Dep=1 & 123 & & & \\
\hline
\end{tabular}


Source :Processed data using eviews

The above equation is a logistic regression equation where the dependent variable is dichotomous scale and cannot be interpreted directly. To be interpreted, first things is the coefficient value of each variable must be eksponensialkan (odd ratio). The following is a mathematical equation for logistic regression after exponential:

$\operatorname{CSRA}_{i}=-2,67+2,12 E S I_{i}+1,05 L E V_{i}+2,16 O P_{i}$

Based on the above equation, it can be seen that the regression coefficient of all independent variables is positive. This shows that there is a positive relationship between the independent variable and the dependent variable.

The z-statistic probability of all the independent variables are smaller than the alpha level of 0.05 . Therefore, industry type variables, leverage and operations have a significant effect on CSR Assurance at a 95\% confidence level (see table 2)

In other words, if the industrial type of a company has higher risk or higher profile, then the greater the chance for a company to obtain CSR Assurance from a third party. If the level of leverage or debt-to-equity ratio of a company is higher, then the greater the chance for a company to obtain third-party assurance for their sustainability report. In addition, the wider the operational scope of a company, the greater the opportunity for a company to obtain CSR Assurance from a third party.

Testing the Second Equation (Multiple Linear Equations). Classic assumption test

Normality test. Jarque-Bera probability is 0.1337 . Because the probability value of Jarque-Bera is greater than the alpha level of 0.05 , it can be concluded that at the $95 \%$ confidence level, the residuals of the second equation are normally distributed.

Multicollinearity Test. The correlation value between independent variables is no more than 0.80 . Therefore, it can be concluded that there is no multicollinearity between the independent variables in the second equation.

Heterocedasticity test. Probability $\mathrm{F}$ has a value of 0.1556 where the value is greater than the alpha level of 0.05 . Therefore, at a $95 \%$ confidence level, it can be concluded that the second regression equation is free from heterocedasticity.

Feasibility Test Model. The probability value $\mathrm{F}$ is 0.009 where this value is smaller than the alpha level of 0.05 . Therefore, at the $95 \%$ confidence level it can be concluded that the independent variable has a significant effect on the dependent variable and the independent variable is feasible to explain its influence on the dependent variable. Adjusted R-Squared value of 0.04264. This value shows that CSR Assurance has an influence proportion on company value of $4.26 \%$, while the remaining $95.74 \%$ is influenced by other variables which are not contained in multiple linear regression models. 
Table 3. Multiple Linier Regression Result

\begin{tabular}{|c|c|c|c|c|}
\hline variable & Coefficient & Std. Error & t-Statistic & Prob. \\
\hline $\mathrm{C}$ & 3.970727 & 0.179635 & 22.10437 & 0.0000 \\
\hline CSRA & 0.492294 & 0.190136 & 2.589162 & 0.0103 \\
\hline ESI & -0.016654 & 0.112189 & -0.148442 & 0.8821 \\
\hline LOG(LEVERAGE) & -0.078408 & 0.040509 & -1.935582 & 0.0544 \\
\hline R-squared & 0.057074 & \multicolumn{2}{|c|}{ Mean dependent var } & 4.334116 \\
\hline Adjusted R-squared & 0.042642 & \multicolumn{2}{|c|}{ S.D. dependent var } & 0.686637 \\
\hline S.E. of regression & 0.671838 & \multicolumn{2}{|c|}{ Akaike info criterion } & 2.062198 \\
\hline Sum squared resid & 88.46775 & \multicolumn{2}{|c|}{ Schwarz criterion } & 2.128164 \\
\hline Log likelihood & -202.2198 & \multicolumn{2}{|c|}{ Hannan-Quinn criter. } & 2.088893 \\
\hline F-statistic & 3.954572 & \multirow{2}{*}{\multicolumn{2}{|c|}{ Durbin-Watson stat }} & 1.177857 \\
\hline Prob(F-statistic) & 0.009105 & & & \\
\hline
\end{tabular}

Source : Processed data using eviews

Based on multiple linear regression tests that have been done, it can be compiled mathematical equations multiple linear regression models as follows

$$
\text { MARKETVALUE } E_{i}=3,97+0,49 \operatorname{CSRA}_{i}-0,016 E S I_{i}-0,078 L E V_{i}
$$

Based on the equation above, it can be seen that the regression coefficient of the CSRA variable is positive. This shows that there is a positive relationship between CSRA variables and MARKET VALUE variables. If the company decides to obtain a third party assurance CSR, then the decision will increase the value of the company.

In addition, for ESI and LEV variables have a negative coefficient. This shows the existence of a negative relationship between industry type variables with firm value, and a negative relationship between leverage variables with firm value.

Testing the First Hypothesis (H1). Industrial type variable (ESI) has a $\mathrm{z}$ value of 3,459 and a probability value of 0,0005 (table 2$)$. Probability value $(0,0005)<(0,1 ; 0,05 ; 0,01)$ which means that industry type variables have a significant effect on CSR Assurance at a significance level of $1 \%, 5 \%, 10 \%$ and $\mathrm{H} 1$ accepted. Therefore, it can be concluded that industry type variable statistically have a positive and significant effect on the CSR Assurance variable.

Testing of the Second Hypothesis (H2). The leverage variable (LEV) has a $\mathrm{z}$ value of 2.539 and a probability value of 0.0111 (table 2$)$. Probability value $(0.01)<(0.0111)$ $<(0.05 ; 0.01)$ which means that the leverage variable has a significant effect on CSR Assurance at a significance level of 5\% and 10\%, and does not have a significant effect on $1 \%$. However, the coefficient value in the regression model shows a positive effect, so $\mathrm{H} 2$ is rejected. Therefore, it can be concluded that the leverage variable statistically has a positive and significant effect on the CSR Assurance variable. 
Testing of the Third Hypothesis (H3). The operational coverage variable (OP) has a $\mathrm{z}$ value of 3.064 and a probability value of 0.0022 (table 2). Probability value $(0.0022)$ $<(0.1 ; 0.05 ; 0.01)$ where it means that the operational coverage variable has a significant effect on CSR Assurance at a significance level of 1\%, 5\%, 10\% and $\mathrm{H} 3$ accepted. Therefore, it can be concluded that the operational coverage variable statistically has a positive and significant effect on the CSR Assurance variable.

Testing of the Fourth Hypothesis (H4). Variable CSR Assurance (CSRA) has a t value of 2.589 and a probability value of 0.01 (table 2 ). Probability value $(0,007)<(0,1 ; 0,05$; $0,01)$ where it means that the CSR Assurance variable has a significant effect on firm value at a significance level of 1\%,5\%,10\% and $\mathrm{H} 4$ accepted

\section{DISCUSSION}

H1: Industrial type has a significant positive effect on CSR Assurance. In this research, industry type variable statistically have a positive and significant effect on the CSR Assurance variable. According to (Purwanto, 2011) that companies included in the type of high profile industry have a tendency to carry out more CSR activities and disclosures. This happens because companies have a higher risk and are sensitive to the environment, politics and others. Therefore, the company seeks to convince all stakeholders or stakeholders that all social and environmental activities reported in sustainability report do occur. This can be achieved by obtaining assurance and attaching assurance statements from third parties in the sustainability report.

H2: Leverage has a significant negative on CSR Assurance. In this research, leverage variable statistically has a positive and significant effect on the CSR Assurance variable. The results of this test are not in accordance with the existing theory. This might happen because companies that have high leverage ratios also have high financial risks. In other words, companies need to guarantee the sustainability of the company in the future to stakeholders. Therefore, companies tend to obtain CSR Assurance from third parties so that stakeholders become more confident about the credibility of the information reported in the sustainability report and the sustainability of the company in the future.

H3: Operational coverage has a significant positive impact on CSR Assurance. In this research, operational coverage variable statistically has a positive and significant effect on the CSR Assurance variable. Demands for reporting social information are higher for multinational companies compared to companies that only operate in domestic areas. In addition, the quality of information becomes more questionable if the company has a broad or international operational area. Therefore, the company needs to obtain CSR Assurance from third parties to ensure that the information that has been reported is qualified and reliable from an independent party.

In addition, based on signaling theory, companies that have a broad scope to go abroad tend to convey broader and more quality corporate CSR information in order to accommodate the wishes of shareholders abroad in obtaining information that the company has carried out its social responsibility well. Therefore, sustainability reports 
should be transparent and reliable, where this can be achieved by obtaining assurance from third parties

H4: CSR Assurance has a significant positive effect on firm value. CSR Assurance variable has a significant effect on firm value. The positive relationship between CSR Assurance and company value shows that if the company obtains CSR Assurance, then the value of the company tends to be higher. Based on the signal theory that sustainability reporting with assurance statements from third parties is able to increase the credibility of the information reported. This can provide a positive signal to stakeholders and is believed to increase company value. The control variable in this hypothesis is leverage and industry type. Leverage has a significant effect on the level of $10 \%$ on firm value while the type of industry does not have a significant effect on firm value.

Implications of Research Results. The implication of the research results for companies is that with this research, companies will be more aware of the importance of obtaining CSR Assurance from third parties. The company will realize that industry type, leverage and operational coverage can demand and influence the company's decision to obtain CSR Assurance from an independent party. In addition, the company will also realize that the costs incurred for obtaining assurance are not only to increase the credibility of information, but can have implications for the value of the company.

\section{CONCLUSION}

Conclusion. Based on the results of research and discussion, it can be concluded that:

1. The type of company industry has a significant positive effect on the company's decision to obtain CSR Assurance. The more sensitive an industry is, the greater the company's need to gain credibility for the CSR disclosure reports it composes

2. Leverage has a significant positive effect on the company's decision to obtain CSR Assurance. The results of this test are not in accordance with the existing theory. This might happen because companies that have high leverage ratios also have high financial risks. Therefore, companies tend to obtain CSR Assurance from third parties so that stakeholders become more confident about the credibility of the information reported in the sustainability report and the sustainability of the company in the future.

3. Operational coverage of the company has a significant positive effect on the company's decision to obtain CSR Assurance. The results of this test are in line with signaling theory where companies that have a broad scope to go abroad tend to convey broader and more quality CSR information in order to accommodate the wishes of shareholders abroad in obtaining information that the company has implemented its social responsibility well.

4. The company's decision to obtain CSR Assurance has a significant positive effect on firm value. These results are in line with the results of (Indyanti, 2017) research which also supports signaling theory where companies that present assurance statements tend to have higher corporate values. 
Limitations. This study has several limitations: (1) Company that report assurance statement, can only be seen from the sustainability report in online form. Meanwhile, sometimes companies do not attach an Assurance Statement from a third party in the report because this statement is additional not the main part of the sustainability report. (2) This study has a relatively small R-Squared level, which is $10.37 \%$ for the logistic regression equation and $4.26 \%$ for the multiple linear regression equation. (3) The research period is relatively short, which is only one year in 2016.

Suggestions. Based on previous limitations, some suggestions for further research can be drawn as follows: (1) For further research, it is expected that the determination of whether or not a CSR assurance exists, based on proof of Assurance Statement from third parties not only in online form; (2) For further research, it is expected to add variables, both independent variables and control variables so that the R-Squared value can increase and a more ideal equation model is obtained; (3) Future studies are expected to extend the research period in order to predict the results of long-term research

\section{REFERENCES}

Andriyanto, R.Widdie and Metalia Mega. (2011) "Perbandingan Tingkat Kelengkapan Mandatory Disclosure dan Voluntary Disclosure InformasiAkuntansiAntaraIndustri High-Profile dan Low-Profile”. JurnalAkuntansidanInvestasi, 12 (1), 15-35.

Bawono,A.A.(2015). "Pengaruh Ukuran Perusahaan, Leverage, Profitabilitas, Cakupan Operasional Perusahaan, Dan Sertifikasi Iso 14001 Terhadap Pengungkapan Corporate Social Responsibility". (Retrieved from: http://eprints.undip.ac.id/46374/1/07_BAWONO.pdf / 18-11-2017)

Branco, Manuel Castelo (2014). "Factors influencing the assurance of sustainability reports in the context of the economic crisis in Portugal", Managerial Auditing Journal, 29 (3): 237 - 252. DOI :10.1108/MAJ-07-2013-0905.

Cho, C. H., G. Michelon, D. M. Patten, dan R. W. Roberts (2014). "CSR report assurance in the USA: an empirical investigation of determinants and effects (Master's thesis"). Sustainability Accounting, Management and Policy Journal, 5 (2), 130-148. DOI:10.1108/SAMPJ-01-2014-0003.

Falichin, Muh. Zulfa Minachul dan Sri, Handayani (2011). "Pengaruh Corporate Social Responsibility Disclosure terhadap Reaksi Investor dengan Environmental Performance Rating dan Corporate Governance sebagai Variabel Moderasi”. Undergraduate Thesis, Universitas Diponegoro.

Gray, R., Javad, M., Power, David M., and Sinclair C. Donald., (2001). "Social And Environmental Disclosure, And Corporate Characteristic: A Research Note And Extension", Journal of Business Finance and Accounting, 28 (3), 327-356.

Haniffa, R. and Cooke, T. E. (2005). The impact of culture and governance on corporate social reporting. Journal of Accounting and Public Policy. DOI: 10.1016/j.jaccpubpol.2005.06.001.

Haryanto, Melinda dan Silvia Dewiyanti., (2017). "Persepsi Mahasiswa Akuntansi terhadap Manfaat dan Ketidakbermanfaatan Sustainability Reporting Perusahaan". Jurnal Riset Akuntansi Terpadu, 10 (1), 87-102. 
Husnan, Suad (2008). Manajemen Keuangan: Teoridan Penerapan (Keputusan Jangka Panjang), Buku 1, Edisi 4. Yogyakarta: BPFE.

Indyanti, J. A., (2017). Assurance Laporan Keberlanjutan: Determinan Dan Konsekuensi Terhadap Nilai Perusahaan. Undergraduate Thesis: Universitas Diponegoro.

Lako, Andreas., (2010). Dekonstruksi CSR \& Reformasi Paradigma Bisnis \& Akuntansi. Jakarta: Penerbit Erlangga.

Moussu, (2014). Do Leveraged Firms Underinvest in Corporate Social Responsibility? Evidence from Health and Safety Programs in U.S. Firms. J Bus Ethics ,135: 715729. (Retrieved May 15, 2017).

Purwanto, A., (2011). Pengaruh Tipe Industri, Ukuran Perusahaan, Profitabilitas, Terhadap Corporate Social Responsibility. Jurnal Akuntansi \& Auditing 8, 1st : 1229.

Rakhman, A., (2017). Pengaruh Karakteristik Perusahaan Terhadap Keputusan Penerapan Assurance Laporan Keberlanjutan. Master's thesis, Universitas Singaperbangsa Karawang. 2, (1), 218-232.

Ross, S.A. (1977). The Determination of Financial Structure: The Incentive-Signaling Approach. The Bell Journal of Economics, 8: 23-40.

Suhardjanto, Djoko dan Miranti, L., (2009). Praktik Penerapan Indonesian Environmental Reporting Index dan Kaitannya dengan Karakteristik Perusahaan. JAAI, 13 (1), 6367.

Utomo, Muhammad Muslim. (2000). Praktek Pengungkapan Sosial Pada Laporan Tahunan Perusahaan di Indonesia (Studi Perbandingan Antara PerusahaanPerusahaan High Profile dan Low Profile). Simposium Nasional Akuntansi III. Jakarta.

Wibowo, E., (2016). Influence Return on Equity (ROE), Return on Assets (ROA), Earning Per Share (EPS), Price Earning Ratio (PER) And Debt to Equity Ratio (DER) Share Price of Automotive and Component Companies Listed on Indonesia Stock Exchange (IDX) in 2010-2013. (Retrieved from: jimfeb.ub.ac.id/index.php/jimfeb/article/view/3069/18-11-2017). 